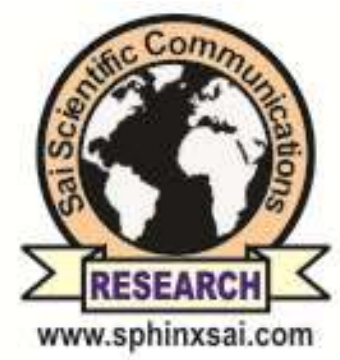

International Journal of PharmTech Research CODEN (USA): IJPRIF, ISSN: 0974-4304, ISSN(Online): 2455-9563

Vol.13, No.01, pp 44-51,

2020

\title{
A New Stability Indicating RP-HPLC Method for Determination of Chlorthalidone, Telmisartan and Cilnidipine in Bulk and Tablet Dosage Form
}

\author{
S.Afreen Sultana ${ }^{1 *}$, Patta.Salomi ${ }^{1}$, T.VimalakKannan ${ }^{2}$, \\ Dr.K.Ravindra Reddy ${ }^{3}$
}

${ }^{1 *}$ M.Pharm, Dept.of Pharmaceutical Analysis, P.Rami Reddy Memorial college of Pharmacy, Kadapa, Andhra Pradesh, India.

${ }^{1}$ Associate Professor, Dept. of Pharmaceutical Analysis and Quality Assurance, P.Rami Reddy Memorial college of Pharmacy, Kadapa, Andhra Pradesh, India.

${ }^{2}$ Associate Professor, Dept. of Pharmaceutical Analysis, P.Rami Reddy Memorial college of Pharmacy, Kadapa, Andhra Pradesh, India.

${ }^{3}$ Principal, Professor in Dept. of Pharmaceutics, P.Rami Reddy Memorial college of Pharmacy, Kadapa, Andhra Pradesh, India.

\begin{abstract}
In present study, accurate, precise, rapid and sensitive stability indicting HPLC-UV method has been established for quantification of Telmisartan, Cilnidipine and Chlorthalidone simultaneously in Tablet and bulk. Telmisartan, Cilnidipine and Chlorthalidone were resoluted on Sunsil $\mathrm{C}_{18}$ column $(4.6 \mathrm{mmx} 250 \mathrm{~mm} ; 5 \mu \mathrm{m})$ using mobile phase containing Acetonitrile and Potassium dihydrogen phosphate in 50:50(v/v) ratio with flow rate of $1 \mathrm{ml} / \mathrm{min}$ at $238 \mathrm{~nm}$. Concentrations were linear over the range of $40-120 \mu \mathrm{g} / \mathrm{ml}$ for Telmisartan, $10-30 \mu \mathrm{g} / \mathrm{ml}$ for Cilnidipine and $6.25-18.75 \mu \mathrm{g} / \mathrm{ml}$ for Chlorthalidone. The percentage recovery was found to be 99.70-100.51\% for Telmisartan, 98.41-100.49\% for Cilnidipine and 99.34-100.48\% for Chlorthalidone. \% RSD for peak area was $0.069 \%$ for Telmisartan, $0.058 \%$ for Cilnidipine and $0.057 \%$ for Chlorthalidone shows that the proposed method is precise. Force-degradation studies have not shown any observable change in the results and hence the proposed method is stability indicating and hence the method is suitable for routine analysis of Telmisartan, Cilnidipine and Chlorthalidone in bulk and tablet dosage form.

Keywords : HPLC, Telmisartan, Cilnidipine, Chlorthalidone, Acetonitrile, Potassium dihydrogen phosphate.
\end{abstract}

Introduction:

Hypertension frequently referred to as a high blood pressure which is the consequence of higher pressure levels of blood. Blood pressure measurement flowing via blood vessels and blood resistance amount as blood is pumped by heart. (1-3)

S.Afreen Sultana et al / International Journal of PharmTech Research, 2020,13(1): 44-51. 
Although blood pressure levels are alarmingly large, there may be no signs. Some individuals of hypertension have narrowness of breath, nosebleeds, headaches and chest pain with blood in urine. These symptoms are not very particular and will not be disclosed unless a health-threatening blood pressure rate is met. $(4,5)$

\section{Chlorthalidone/ Telmisartan/ Cilnidipine Combination Formulation:}

This three combination drugs is used in elevated blood pressure chemotherapy [6-8]. Chlorthalidone is a diuretic, anti hypertensive, Thiazide drug. Chemical formula is $\mathrm{C}_{14} \mathrm{H}_{11} \mathrm{ClN}_{2} \mathrm{O}_{4} \mathrm{~S}$.It is useful for treating high blood pressure, oedema, and hypertrophy of ventricles and prevention of calculi from kidneys. (911).Telmisartan is an antagonist of angiotensin two receptor, antihypertensive, It is a derivative of benzene, cardiovascular drug.

Chemical formula is $\mathrm{C}_{33} \mathrm{H}_{30} \mathrm{~N}_{4} \mathrm{O}_{2}$.It is useful in high blood pressure, kidney disorders in diabetes, also in heart failure. (12-14)Cilinidipine is Hyperkalemia, antiarrhythmic drug; it is a calcium channel inhibitor, Hypotensive drug. Chemical formula is $\mathrm{C}_{27} \mathrm{H}_{28} \mathrm{~N}_{2} \mathrm{O}_{7}$. It is useful in Hypertension, diabetes with albumunaria; It is also used in kidney diseases of chronic nature.(15-17)

\section{Table No.1: Tabulated form of selected Drugs}

\begin{tabular}{|l|l|l|}
\hline Drug & Properties \\
\hline Chlorthalidone & $\begin{array}{l}\text { Diuretic } \\
\text { Anti Hypertensive } \\
\text { Thiazide drug }\end{array}$ \\
\hline Cilnidipine
\end{tabular}

\section{Review of Literature:}

Literature review reveals that few methods have been reported for determination of chlorthalidone, telmisartan and cilinidipine by UV-spectroscopic method (18) and High Performance Liquid Chromatography Methods. (19-21)

In the proposed analytical work, we have made an attempt to develop a new, simple accurate, precise and sensitive method and to validate the method according to ICH [Q2-R1] guidelines (22).

\section{Experimental Section:}

\section{Instrument employed:}

The HPLC system consisted of waters 2695 solvent delivery model and waters 2669 PDA detector with reverse phase ODS Sunsil $\mathrm{C}_{18}(4.6 \times 250 \mathrm{~mm}: 5 \mu \mathrm{m})$.Data acquisition was performed by empower 2 software. 


\section{Materials:}

Chlortahlidone, Telmisartan, Cilinidipine were obtained as gifts from Rainbow laboratories, Hyderabad. Acetonitrile, Methanol and Millipore water system are of HPLC grade and Potassium dihydrogen phosphate were procured from Yarrow chem. products Mumbai. All reagents used in the present study were of analytical grade.

\section{Preparation of stock solution:}

Stock solution of Telmisartan $(400 \mu \mathrm{g} / \mathrm{ml})$, Cilnidipine $(100 \mu \mathrm{g} / \mathrm{ml})$ and Chlorthalidone $(65 \mu \mathrm{g} / \mathrm{ml})$ was prepared by the direct weighing $40 \mathrm{mg}, 10 \mathrm{mg}$ and $6.5 \mathrm{mg}$ Telmisartan, Cilnidipine and Chlorthalidone, respectively with succeeding dissolution in diluent in a volumetric flask (capacity $100 \mathrm{ml}$ ).

\section{Preparation of working standard:}

Solutionis developed from stock solution with concentration level of $80 \mu \mathrm{g} / \mathrm{ml}$ telmisartan, $20 \mu \mathrm{g} / \mathrm{ml}$ cilnidipine and $12.50 \mu \mathrm{g} / \mathrm{ml}$ chlorthalidone concentration.

\section{Method Development:}

A simple RP-HPLC method was developed on Sunsil -ODS $\mathrm{C}_{18}(4.6 \times 250 \mathrm{~mm}: 5 \mu \mathrm{m})$ column using Acetonitrile: Potassium dihydrogen phosphate(50:50)as mobile phase with flow rate of $1.0 \mathrm{ml} / \mathrm{min}$ at $238 \mathrm{~nm}$ detection with runtime 8minutes.The retention times for Chlorthalidone, Telmisartan and Cilnidipine were $1.782,2.266,2.828 \mathrm{mins}$ respectively. RP-HPLC Chromatogram of 3selected drugs it is represented in Figure-1

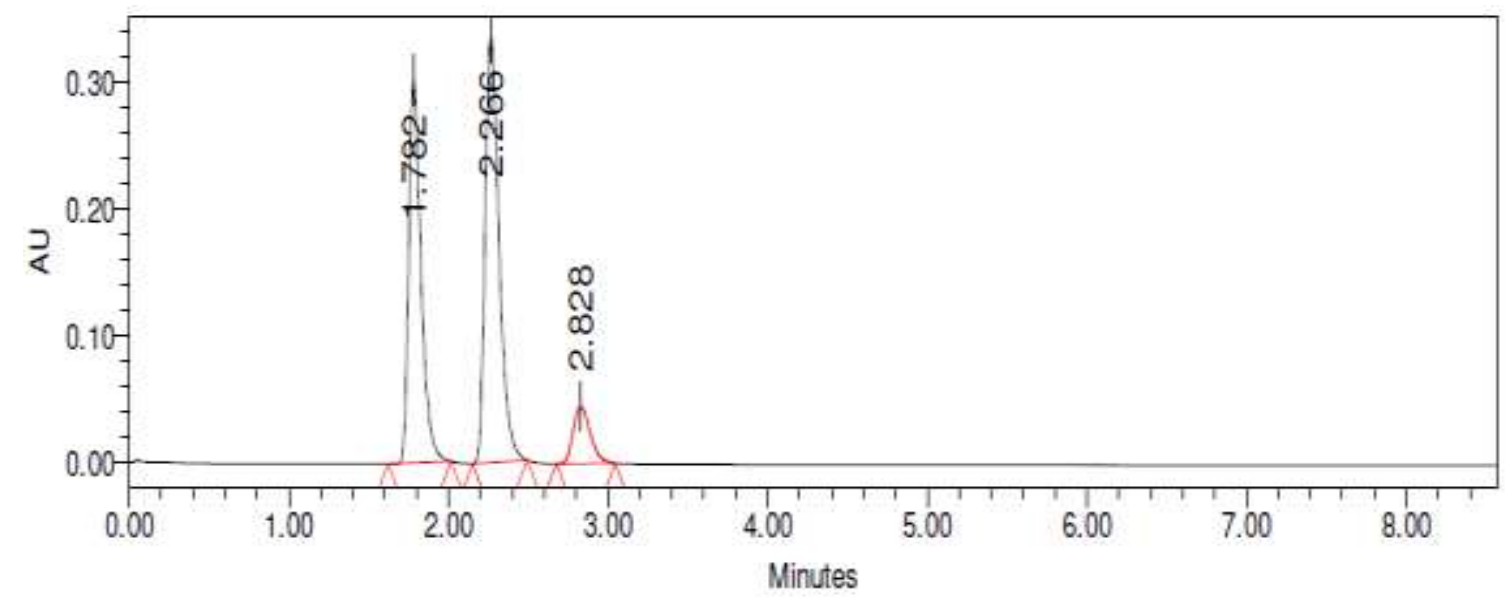

\begin{tabular}{|c|c|c|c|c|c|c|}
\hline Name & $\begin{array}{c}\text { Retention } \\
\text { Time }\end{array}$ & Area & $\begin{array}{c}\% \\
\text { Height }\end{array}$ & $\begin{array}{c}\text { USP } \\
\text { Resolution }\end{array}$ & $\begin{array}{c}\text { USP } \\
\text { Tailing }\end{array}$ & $\begin{array}{c}\text { USP Plate } \\
\text { Count }\end{array}$ \\
\hline CHL & 1.782 & 1623300 & 44.24 & & 1.48 & 8669 \\
\hline TEL & 2.266 & 2029927 & 49.10 & 3.19 & 1.42 & 7325 \\
\hline CIL & 2.828 & 339137 & 6.65 & 3.12 & 1.28 & 9349 \\
\hline
\end{tabular}

Fig No.1: Chromatogram of selected Drugs.

\section{Method Validation:}

\section{Selectivity:}

The method selectively eluted for Chlorthalidone, Telmisartan, and Cilnidipine. There was no interference of placebo and mobile phase at retention time of drugsand were represented in Figure- 2 and Figure -3 . 


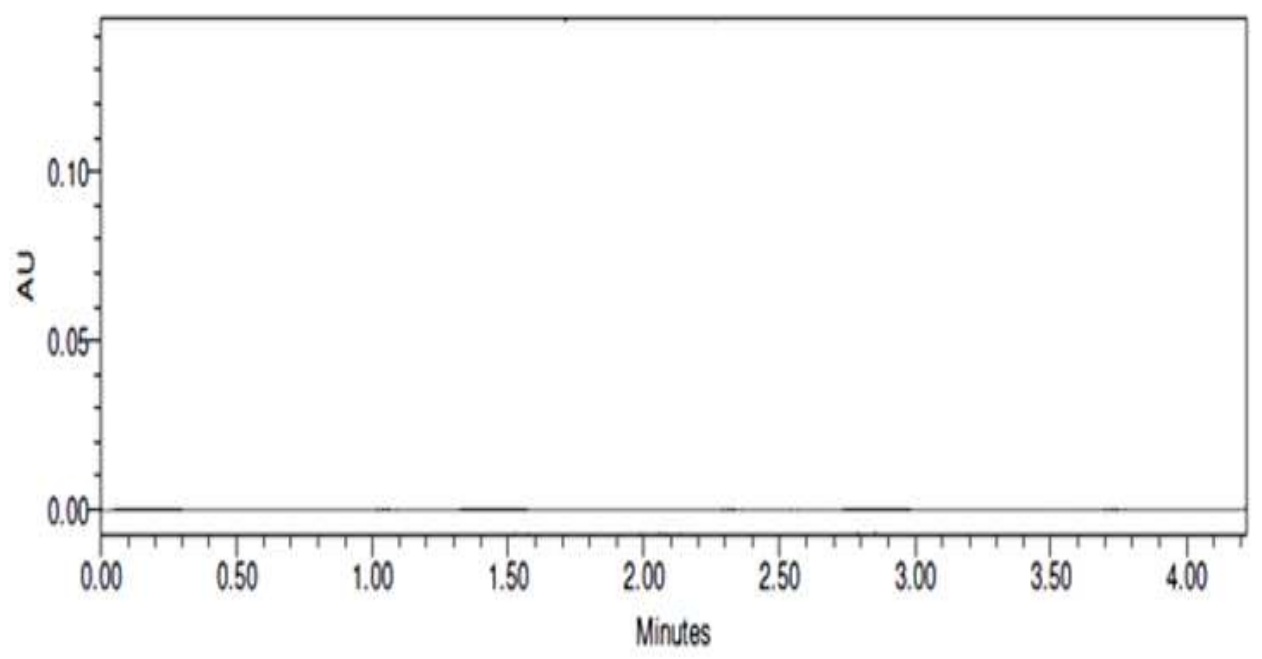

Fig No.2: Chromatogram of Mobile phase

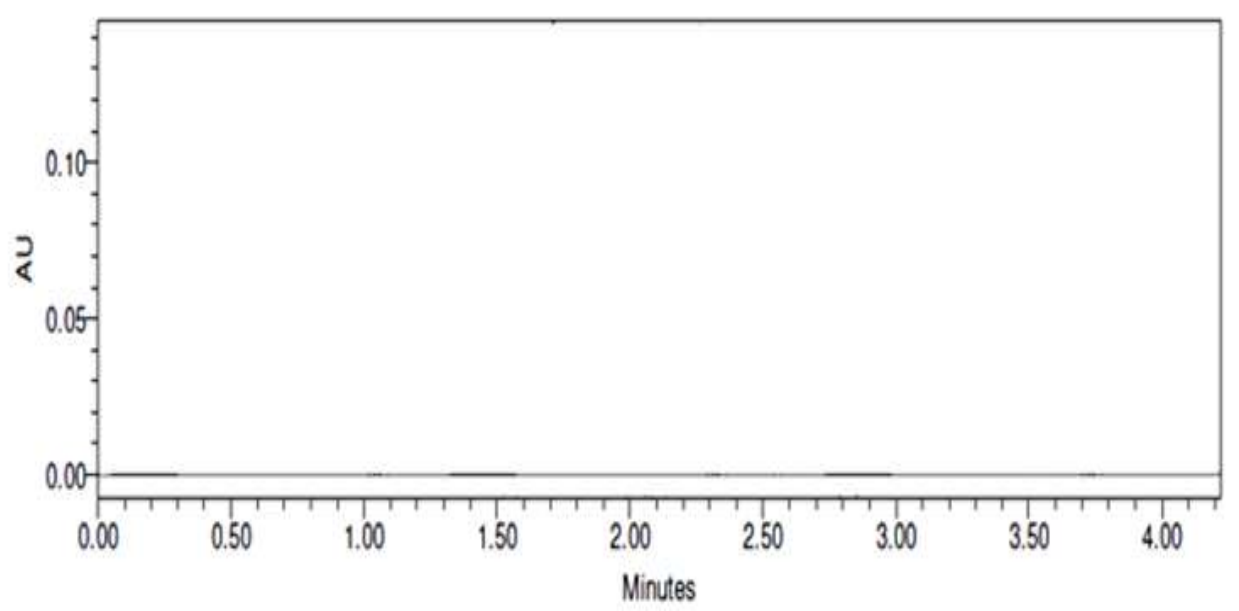

Fig No.3: -Chromatogram of Placebo

\section{Sensitivity:}

The studies were performed by injecting lowest concentrationin the calibration curve for six times and assay was determined and it was between $99-102 \%$. The results are tabulated in Table- 2 .

Table No.2:\% Assay of Selected Drugs

\begin{tabular}{|l|l|l|l|}
\hline S.NO & $\begin{array}{l}\text { CHLORTHALIDONE } \\
\mathbf{N = 6 . 2 5}\end{array}$ & $\begin{array}{l}\text { TELMISARTAN } \\
\mathbf{N = 4 0}\end{array}$ & $\begin{array}{l}\text { CILNIDIPINE } \\
\mathbf{N}=\mathbf{1 0}\end{array}$ \\
\hline 1 & 6.21 & 39.8 & 9.9 \\
\hline 2 & 6.19 & 41 & 10.2 \\
\hline 3 & 6.20 & 41.2 & 10.1 \\
\hline 4 & 6.23 & 40.9 & 10 \\
\hline 5 & 6.21 & 40.5 & 9.8 \\
\hline 6 & 6.24 & 41.1 & 9.9 \\
\hline $\begin{array}{l}\text { Mean } \\
\text { Concentration }\end{array}$ & $\mathbf{6 . 2 1}$ & $\mathbf{4 0 . 7 5}$ & $\mathbf{9 . 9 8}$ \\
\hline \%Assay & $\mathbf{9 9 . 3 6 \%}$ & $\mathbf{1 0 1 . 8 7 \%}$ & $\mathbf{9 9 . 8 \%}$ \\
\hline
\end{tabular}




\section{Linearity:}

A series of solutions were prepared using Chlorthalidone $6.25 \mu \mathrm{g} / \mathrm{ml}$ to $18.75 \mu \mathrm{g} / \mathrm{ml}$, Telmisartan 40 $\mu \mathrm{g} / \mathrm{ml}$ to $120 \mu \mathrm{g} / \mathrm{ml}$ and Cilnidipine $10 \mu \mathrm{g} / \mathrm{ml}$ to $30 \mu \mathrm{g} / \mathrm{ml}$ of target concentrations. Data was illustrated in Table-3 and in Figure 4, 5, 6.

Table No.3-Data achieved with Linearity Test

\begin{tabular}{|l|l|l|l|l|l|}
\hline $\begin{array}{l}\text { Area of } \\
\text { chlorthalidone }\end{array}$ & $\begin{array}{l}\boldsymbol{\mu g} / \mathbf{m l ~ o f} \\
\text { chlorthalidone }\end{array}$ & $\begin{array}{l}\text { Area of } \\
\text { Telmisartan }\end{array}$ & $\begin{array}{l}\boldsymbol{\mu g} / \mathbf{m l ~ o f} \\
\text { telmisartan }\end{array}$ & $\begin{array}{l}\text { Area of } \\
\text { cilnidipine }\end{array}$ & $\begin{array}{l}\boldsymbol{\mu g} / \mathbf{m l ~ o f} \\
\text { cilnidipine }\end{array}$ \\
\hline 1811831 & 6.25 & 2254147 & 40 & 368028 & 10 \\
\hline 2726578 & 9.38 & 3385450 & 60 & 574575 & 15 \\
\hline 3632954 & 12.50 & 4519670 & 80 & 766332 & 20 \\
\hline 4549363 & 15.625 & 5649318 & 100 & 957883 & 25 \\
\hline 5451538 & 18.75 & 6776558 & 120 & 1147103 & 30 \\
\hline
\end{tabular}

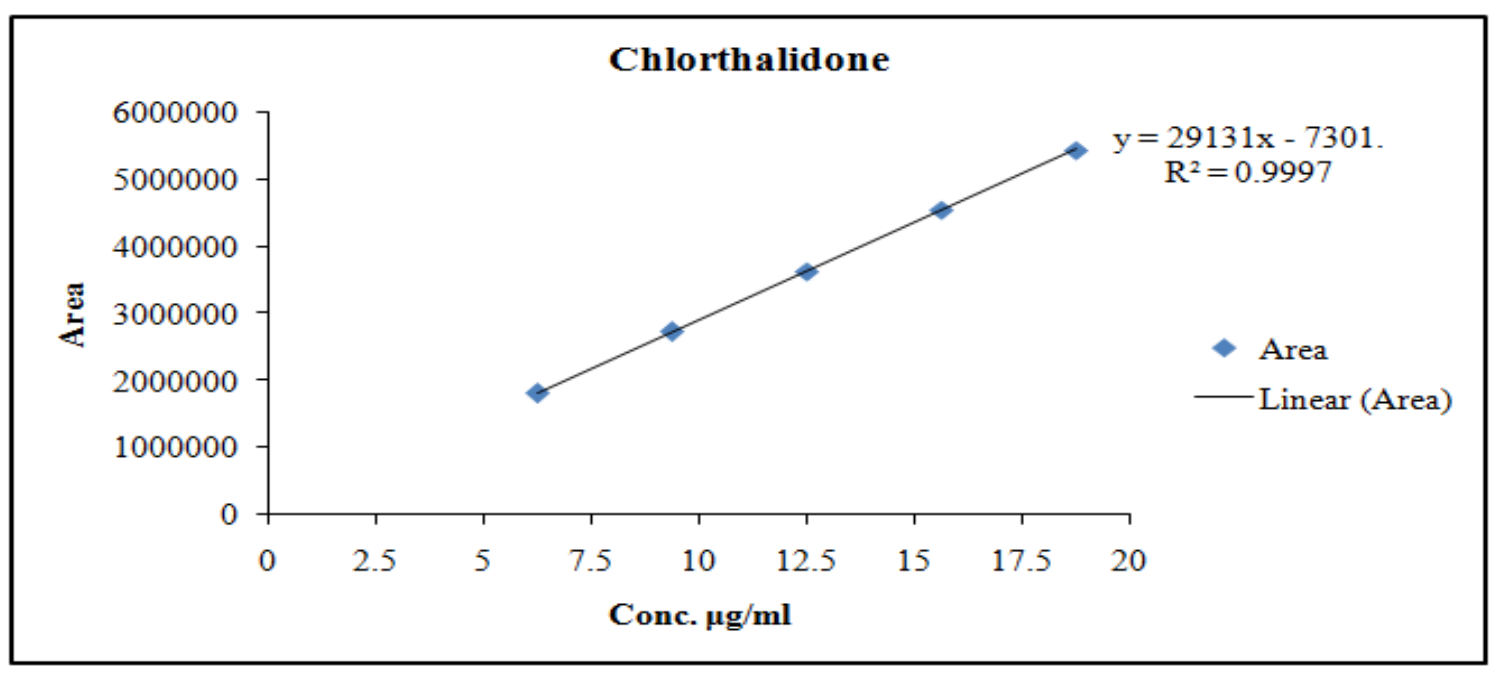

Fig No.4: Linearity of Chlorthalidone

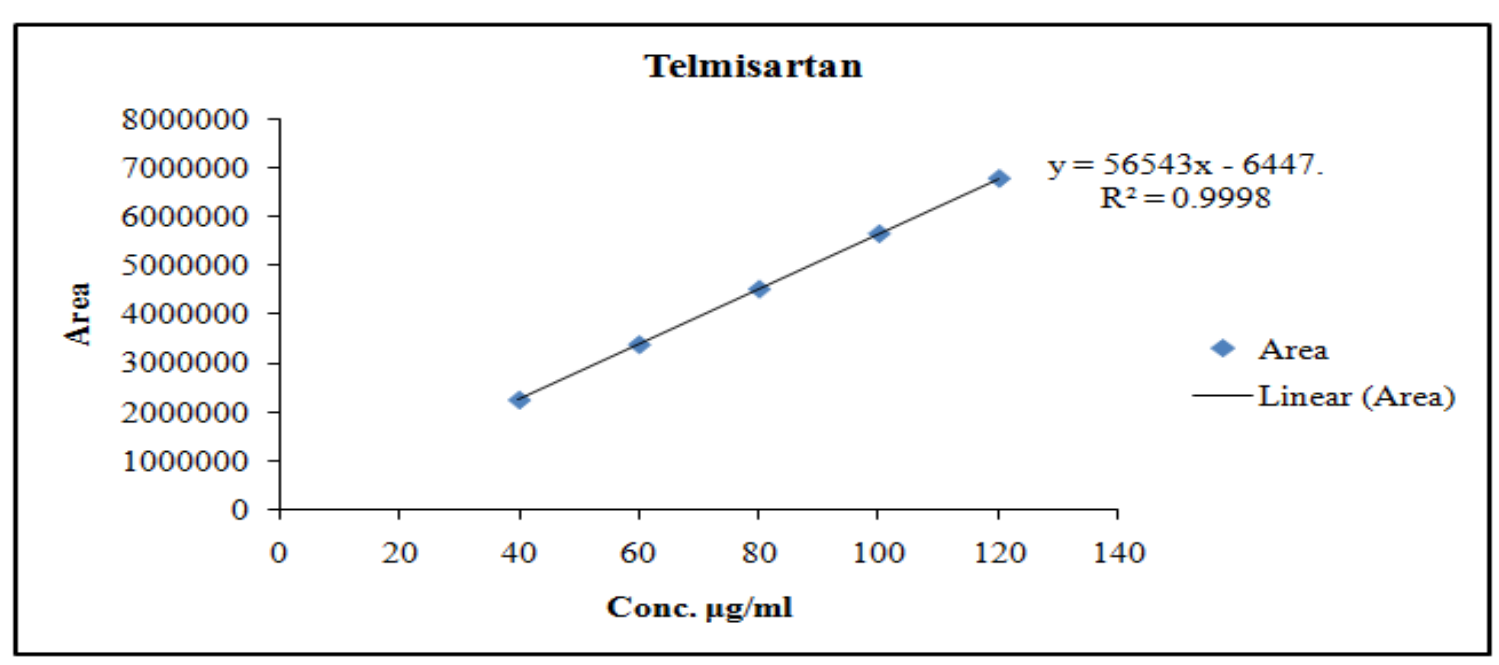

Fig No.5: Linearity of Telmisartan 


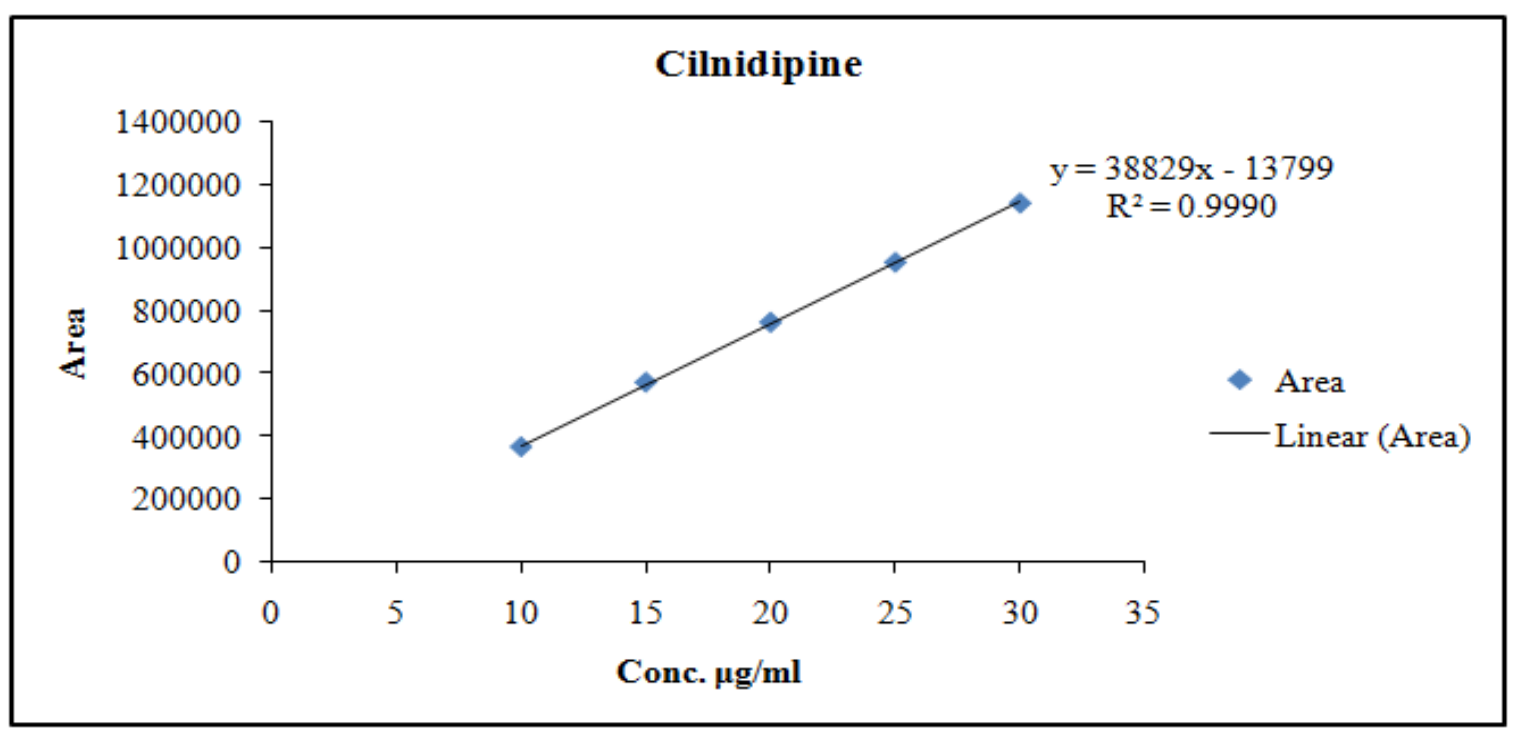

Fig No.6: Linearity of Cilnidipine

\section{Accuracy:}

A study of accuracy was conducted. Drug Assay was performed in triplicate as per test method with equivalent amount of Chlorthalidone, Telmisartan and Cilnidipine in to each volumetric flask for each spike level to get the concentration of Chlorthalidone, Telmisartan and Cilnidipine solutions equivalent to 50\%, $100 \%$, and $150 \%$ of the labelled amount as per test method. The average \%recovery of Chlorthalidone, Telmisartan and Cilnidipine. The result for Accuracy data is shown in Table-4.

Table No.4:Accuracy Data for selected drugs

\begin{tabular}{|c|c|c|c|}
\hline Spiked conc. level & $50 \%$ & $100 \%$ & $150 \%$ \\
\hline \multirow{3}{*}{$\begin{array}{l}\% \text { of Chlorthalidone } \\
\text { recovery }\end{array}$} & 99.79 & 100.48 & 100.36 \\
\hline & 99.34 & 100.10 & 100.44 \\
\hline & 100.02 & 100.17 & 100.17 \\
\hline \% RSD of Chlorthalidone & $0.34 \%$ & $0.22 \%$ & $0.137 \%$ \\
\hline \multirow{3}{*}{$\begin{array}{l}\% \text { of Telmisartan } \\
\text { recovery }\end{array}$} & 99.88 & 100.35 & 100.43 \\
\hline & 100.17 & 100.34 & 100.51 \\
\hline & 99.70 & 100.42 & 100.49 \\
\hline \% RSD of Telmisartan & $0.23 \%$ & $0.0039 \%$ & $0.041 \%$ \\
\hline \multirow{3}{*}{$\begin{array}{l}\text { \% of Cilnidipine } \\
\text { recovery }\end{array}$} & 100.30 & 100.38 & 99.67 \\
\hline & 100.49 & 100.37 & 98.41 \\
\hline & 100.49 & 100.45 & 99.04 \\
\hline \% RSD of Cilnidipine & $0.1 \%$ & $0.043 \%$ & $0.63 \%$ \\
\hline
\end{tabular}

\section{Precision:}

Working Standard solutions were injected six times in to HPLC column and \%RSD for peak areas was determined and it was shown that \%RSD for selected drugs was less than $2 \%$. The result for precision data is shown in Table -5 . 
Table No.5: Precision Data for Selected Drugs

\begin{tabular}{|l|l|l|l|}
\hline Sample inj. No. & Area of chlorthalidone & Area of telmisartan & Area of cilnidipine \\
\hline 1 & 3626458 & 4503984 & 765901 \\
\hline 2 & 3623339 & 4504322 & 765184 \\
\hline 3 & 3625508 & 4509615 & 765051 \\
\hline 4 & 3623412 & 4500829 & 765989 \\
\hline 5 & 3628428 & 4505725 & 765180 \\
\hline 6 & 3627294 & 4501970 & 765000 \\
\hline Avg. & $\mathbf{3 6 2 5 7 4 0}$ & $\mathbf{4 5 0 4 4 0 8}$ & $\mathbf{7 6 5 3 8 4 . 2}$ \\
\hline SD & $\mathbf{2 0 6 8 . 5 2 6}$ & $\mathbf{3 0 9 1 . 5 2 4}$ & $\mathbf{4 4 1 . 1 9 7 2}$ \\
\hline RSD & $\mathbf{0 . 0 0 0 5 7}$ & $\mathbf{0 . 0 0 6 9}$ & $\mathbf{0 . 0 0 5 8}$ \\
\hline \%RSD & $\mathbf{0 . 0 5 7 \%}$ & $\mathbf{0 . 0 6 9 \%}$ & $\mathbf{0 . 0 5 8 \%}$ \\
\hline
\end{tabular}

\section{Degradation studies:}

Force degradation study was performed for selected drugs in different circumstances i.e.,Acid, Base, Peroxide, Heat Dry and Sunlight.\% Degradation for selected drugs was within the limits as per ICH guidelines. The result of degradation studies is shown in Table-6

Table No.6: Results of Degradation studies

\begin{tabular}{|l|l|l|l|}
\hline Degraded with & Area of Chlorthalidone & \% Chlorthalidone Assay & $\begin{array}{l}\text { \% Chlorthalidone } \\
\text { Degraded }\end{array}$ \\
\hline Acid & 3245488 & 89.02 & 10.98 \\
\hline Base & 3516601 & 96.46 & 3.54 \\
\hline Peroxide & 3544535 & 97.23 & 2.77 \\
\hline Heat dry & 3496994 & 95.92 & 4.08 \\
\hline Sunlight & 3461731 & 94.95 & 5.05 \\
\hline Degraded with & Area of Telmisartan & \% Telmisartan assay & $\begin{array}{l}\text { \% Telmisartan } \\
\text { Degraded }\end{array}$ \\
\hline Acid & 4082968 & 90.05 & 9.95 \\
\hline Base & 4302757 & 94.90 & 5.1 \\
\hline Peroxide & 4358184 & 96.12 & 3.88 \\
\hline Heat dry & 4180839 & 92.21 & 7.79 \\
\hline Sunlight & 4299203 & 94.82 & 5.18 \\
\hline Degraded with & Area of Cilnidipine & $\mathbf{\%}$ Cilnidipine assay & $\begin{array}{l}\text { Cilnidipine } \\
\text { Degraded }\end{array}$ \\
\hline Acid & 703872 & 91.80 & 8.2 \\
\hline Base & 718601 & 93.72 & 6.28 \\
\hline Peroxide & 742354 & 96.81 & 3.19 \\
\hline Heat dry & 709813 & 92.57 & 7.43 \\
\hline Sunlight & 728486 & 95.01 & 4.99 \\
\hline
\end{tabular}

\section{Conclusion:}

A simple, sensitive and accurate HPLC-UV Method has been developed for determination of Chlortahlidone, Telmisartan, and Cilnidipine in bulk and tablet dosage form.Both Placebo and mobile phase did not interfere at retention times of drugs which shows that the method selectively resoluted the drugs. The proposed method resulted better \%Recovery compare to existing methods. \%RSD less than $1 \%$ for peak areas shows that the method is precised. The \%Assay for lowest concentration in calibration curve for selected drugs was between $99-101 \%$ which shows that the developed method was sensitive. \% degradation for selected drugs 
was less than $10 \%$ which shows that the proposed method was stability indicating. Hence; the developed method can be used for determination of selected drugs in bulk and tablet dosage form.

\section{References:}

1. Lackland DT; Weber, MA. Global burden of cardiovascular disease and stroke: hypertension at the core. The Canadian journal of cardiology. 2015, 31 (5), 569-71.

2. High Blood Pressure Fact Sheet. CDC. 19 February 2015. Archived from the original on 6 March 2016. Retrieved 6 March 2016.

3. Naish J. Denise Syndercombe. Medical sciences (2 ed.), 2014, p. 562.

4. Fisher ND, Williams GH. Hypertensive vascular disease. In Kasper DL, Braunwald E, Fauci AS, et al. Harrison's Principles of Internal Medicine (16th ed.). New York, NY: McGraw-Hill. 2005, p. 1463-81.

5. Wong T, Mitchell P, Mitchell. The eye in hypertension. Lancet. 2007, 369 (9559), 425-35.

6. O'Brien E, Beevers DG, Lip GYH. ABC of hypertension. London: BMJ Books. 2007.

7. Ehret GB, Munroe PB, Rice KM. Genetic variants in novel pathways influence blood pressure and cardiovascular disease risk. Nature. 2011, 478 (7367), 103-09.

8. Lifton RP, Gharavi AG, Geller DS. Molecular mechanisms of human hypertension. Cell. 2001, 104 (4), 545-56.

9. Chlorthalidone,Pubchem,2019.Availableat:https://pubchem.ncbi.nlm.nih.gov/compound/Chlorthalidon $\mathrm{e}$

10. Chlorthalidone,Drugbank,2019.Availableat:https://www.drugbank.ca/drugs/DB00310

11. Roush GC, Buddharaju V, Ernst ME, Holford TR. Chlorthalidone: mechanisms of action and effect on cardiovascular events. Current Hypertension Reports, 2013, 15 (5), 514-521.

12. Telmisartan,Pubchem,2019.Availableat:https://pubchem.ncbi.nlm.nih.gov/compound/Telmisartan

13. Telmisartan, Drug bank, 2019. Available at: https://www.drugbank.ca/drugs/DB00966

14. Philippe G. A Review of Telmisartan in the Treatment of Hypertension: Blood Pressure Control in the Early Morning Hours. Vascular Health Risk Management, 2006, 2 (3), 195-201.

15. Cilnidipine,Pubchem,2019.Availableat:https://pubchem.ncbi.nlm.nih.gov/compound/5282138

16. Cilnidipine, Drug bank, 2019. Available at: https://www.drugbank.ca/drugs/DB09232

17. Kario K, Ando S, Kido H, Nariyama J, Takiuchi S, Yagi T, Shimizu T, Eguchi K, Ohno M, Kinoshita O, Yamada T, The Effects of the L/N-Type Calcium Channel Blocker (Cilnidipine) on Sympathetic Hyperactive Morning Hypertension. The Journal of Clinical Hypertension. 2013, 15 (2), 133-142.

18. Reddy BH, Spandana B, Mounika D, Sindhu D, Anusha D, Prakash KV. Simultaneous Estimation of Telmisartan, Chlorthalidone and Cilnidipine by Absorbance Correction Method Using UV Spectrophotometry, Indo American Journal of Pharmaceutical Sciences, 2018, 5 (3), 1998-2003.

19. Mathews B, Ramisetti NR, Priyanka P, Mukkanti K, Sarbani P. Development and Validation of a stability indicating RP-HPLC method for simultaneous determination of Telmisartan, Chlorthalidone and Cilnidipine in pharmaceutical combined dosage forms. International Journal of Pharmacy, 2016, 6 (2), 299-311.

20. Mauly PP, Komal PP, Dhaval BP. Development and validation of analytical method for simultaneous estimation of cilnidipine, chlorthalidone and telmisartan in tablet dosage form. World Journal of Pharmacy and Pharmaceutical Sciences, 2016, 5 (6), 1228-1241.

21. Akhilesh S, Anurag M, Sanjay S. Stability indicating simultaneous validation of telmisartan, cilnidipine and chlorthalidone with forced degradation behavior study by RP-HPLC in tablet dosage form. International Journal of Chemical and Pharmaceutical Sciences, 2016, 7 (2), 6-12.

22. International Conference on Harmonization, Validation of analytical procedures: text and methodology Q2 (R1), 2005. 